DOI https://doi.org/10.33766/2524-0323.86.325-338

УДК 343.98:343.3

Б. Г. Розовський,

доктор юридичних наук, професор заслужений юрист України,

завідувач кафедри правознавства

Східноукраїнського національного університету імені В. Даля

(м. Сєвєродонецьк, Україна)

e-mail: rozovskiy@rambler.ru

(iD https://orcid.org/0000-0002-5087-7076

C. P. Тагієв,

доктор юридичних наук, професор,

заслужений юрист України,

начальник кафедри кримінального,

кримінально-виконавчого права

та кримінології

Академії державної пенітенціарної служби

(м. Чернігів, Україна)

e-mail: tagsad@i.ua

iD https://orcid.org/0000-0001-9338-4792

О. В. Бочковий,

кандидат юридичних наук, старший дослідник, провідний фахівець науково-дослідної лабораторії 3

проблем попередження, припинення та розслідування злочинів територіальними органами

Національної поліції України

Луганського державного університету внутрішніх справ імені Е. О. Дідоренка,

(м. Сєвєродонецьк, Україна)

e-mail: bochkin.0583@gmail.com

iD https://orcid.org/0000-0001-7262-3416

\title{
«ГЛАС ВОПИЮЩЕГО В ПУСТЫНЕ» - ЧОМУ?
}

У статті зазначається, що вся історія цивілізації - це повсюдне подолання одвічного упередження: «цього не може бути, тому що не може бути». Незважаючи на відомі свідчення ефективного застосування в слідчій практиці нетрадиційних методів доказування, і сьогодні спостерігається їх ігнорування та відсутність інтересу в необхідності експериментального підтвердження чи спростування цього. Причому сучасний науково-технічний рівень дозволяє дослідним способом підтвердити чи спростувати вказані в статті способи отримання інформації. Підтвердження описаних фактів дозволить підвищити ефективність попередження та припинення, а також розслідування злочинів. Спростування ж цього факту назавжди позбавить від марних дискусій.

Ключові слова: криміналістика, біокомунікація, енергія, доказ, доказування, свідок, злочин, покарання, кримінальна відповідальність.

(C) Розовський Б. Г.,

Тагієв С. Р., Бочковий О. В., 2019 
Постановка проблеми. Численні не тільки наукові відкриття, але й узвичаєні традиційні життєві обряди й уклад в цілому довго сприймалися сучасниками як такі, що не відповідають їх уявленням. Парадокс, але така доля приготована й деяким визнаним у минулому артефактам, чиє пояснення вступило в протиріччя з оновленим рівнем знань. Учений якщо він справжній учений! - не має права відкидати факти тільки тому, що вони не вписуються у встановлені догми або суперечать сучасного світогляду. Він зобов'язаний подавати голос, вимагаючи встановлення істини - визнання необгрунтованого їх відкидання, або в рівній мірі допущених у минулому помилок. На жаль, сьогодні від волі вченого залежить небагато. Рішення приймають особи чи органи, наділені владою, у даному випадку покликані забезпечувати дотримання правопорядку в державі. Їм ми й адресуємо цю статтю.

Не буде перебільшенням твердження, що вся історія цивілізації - це повсюдне подолання одвічного упередження: «цього не може бути, тому що не може бути». Наші далекі предки подолали його, вийшовши з печер та інших природних укриттів, оволодівши, як збиральництвом i полюванням, так і землеробством та скотарством. Нині - це літаки і ракети, важчі за повітря, штучний інтелект і маса інших новацій, неможливість яких доводили досить авторитетні вчені та громадські діячі свого часу.

Але якщо неприйняття нового, незвіданого ще можна пояснити, то не інакше як парадокс розцінюється сама відмова від переосмислення i перевірки з використанням новітніх досягнень науки й техніки явищ i фактів, перспективних у плані сучасної практики, але відкинутих у минулому через неоднорідність отриманих результатів, ідеологічних, релігійних та інших переконань. Їх безліч у різних галузях знань. Однак питання «Чому? Чому щось із користю застосовувалося в минулому й забуте нині?» не порушується. Спробуємо розібратися, наскільки це виправдано в галузі юридичної науки.

Аналіз останніх досліджень і публікацій за вказаною тематикою складно здійснити, адже вони практично відсутні, що й стало підставою для написання статті. При цьому наукові свідчення, результати досліджень та думки експертів будуть наведені нижче.

Формування цілей: акцентувати увагу на необхідності емпіричної перевірки свідчень нетрадиційних способів отримання доказової інформації для можливості практичного використання або ж спростування, для уникнення марних дискусій.

Виклад основного матеріалу. Почнемо з витоків кривавої ворожнечі, провини иे помсти. Дослідники відзначають, що, за звичаєм, коли проливалася кров, члени сім'ї жертви зобов'язані були умиротворяти дух крові актом помсти. Мститися за пролиту кров повинен був найближчий родич убитого. Згідно Мойсеєвого кодексу (Другозаконня, гл. 19:11-13), цей родич іменувався «месником по крові», а сам акт помсти освящався волею Божою. 
Однією з властивостей крові, яка викликала загальне благоговіння, була приписувана їй здатність викривати злочинців і вершити правосуддя. 3 давніх-давен, коли особа відбирала життя в ближнього, вона повинна була виконати найскладніші ритуали, щоб уберегтися від «помсти» крові, яку вона пролила, бо, за повір'ями, разом із кров'ю з жертви виривався $і і ̈$ дух. I цей дух переслідував вбивцю, ходив слідом за ним, викликаючи в нього безумство або смерть. Століттями вважалося, нібито труп почне кровоточити при наближенні або під час дотику вбивці.

«Обвинувальна» властивість крові отримала божественну санкцію в Біблії. Бог сказав до Каїна, який убив брата свого: «Що ти зробив? Голос крові брата твого кличе до мене із землі». (Буття, гл. 4:10). За часів Вільяма Шекспіра свідоцтво крові офіційно визнавалося законом. Мабуть, історія неодноразово підтверджувала ефективність цієї прикмети,тому не дивно, що Шекспір повною мірою використовував ії у своїй трагедії «Річард III». Це повір'я відіграло відому роль у розкритті таємничих убивств і довгий час залишалося частиною британського кримінального законодавства. Існували численні приклади, коли труп кровоточив при наближенні вбивці. Перебуваючи під впливом цього темного прояву, люди, підозрювані у вбивстві, іноді відмовлялися наближатися до трупа й тим самим видавали себе.

Історія англійської юриспруденції знає безліч випадків розкриття найжахливіших злочинів, коли правосуддя вершила кров. У 1613 році неподалік від Таунтона, містечка в південно-західній Англії, було знайдено тіло по-звірячому вбитої вдови. Їй нанесли шістнадцять ножових поранень. Місцевий магістрат скликав усе населення округу в радіусі трьох миль і запропонував усім без винятку мешканцям пройти повз трупа й доторкнутися до нього. Зібралися всі, крім такого собі Бебба, місцевого жителя, який раніше доглядав за покійною. Відсутність останнього здалася городянам підозрілою, почулися погрози й звинувачення на його адресу. Загальна впевненість у його провині була настільки непохитною, що, врешті-решт, Бебб змушений був зізнатися в скоєному злочині. Як з'ясувалося, він убив удову в пориві гніву, коли вона відмовилася вийти за нього заміж, а потім, очевидно, боячись доторкнутися до трупа, утік [1].

Відлуння минулого звичаю живі й понині. Під час похорон і по черзі проходячи повз відкритої труни, ми, самі того не підозрюючи, здійснюємо церемонію, що виникла в ті страшні часи, коли насильницька смерть була звичайним явищем. Віддаючи останню шану покійному, ми беремо участь в старовинному обряді судилища крові, при якому сам небіжчик ніби свідчить про нашу вину або невинуватість.

Не ставимо собі за мету закликати до беззастережного використання в сучасній практиці розслідування досвіду минулих століть. Проте так само $€$ неприйнятним його огульне заперечення. Не можуть все-таки не викликати подиву численні свідоцтва разових виділень крові з трупа вбитого при наближенні до нього вбивці. Усяке може бути: збіг, особливість пози й умов утримання трупа, час настання смерті, погодні умови нарешті. Проте а якщо у цьому все ж щось $є$ ? Не виключено, що не 
всі людські організми однаково реагують на однаковий подразник. Та й спосіб скоєння вбивства, обізнаність жертви про вбивцю, справжній мотив і багато іншого могли мати значення. Не хочеться вірити, що наші далекі предки були настільки недолугі, що кілька століть жили забобонами, а не реальною дійсністю. Чому $б$ сьогодні не зайнятися перевіркою об'єктивності цих фактів?

Сучасна наука дозволяе критично переосмислити навіть деякі фундаментальні закони природи. Тож чому не виникає думка зайнятися повторним аналізом окремих спірних тї проявів? Якщо ж і є якісь сумніви, то вони повинні бути усунуті. А сумніви в порочності слідчої практики минулих століть таки є. Існують також і новітні засоби для їх перевірки. Для цього можуть бути взяті більш тонкі структури організму, ніж кров, наприклад, клітини тіла.

Російський учений К. Г. Коротков ${ }^{1}$ серед інших проблем займався дослідженням життедіяльності клітин трупа після визнаної за медичними критеріями того часу смерті людини. У 1996 році під час деякої «вседозволеності» в країні по пітерському телебаченню показали прямий репортаж із крематорію. «Родзинкою» цієї передачі, яку переглянули не всі (бо транслювалася вона вдень і більше не повторювалася), стало те, що до голови покійного прикріпили датчики електроенцефалографа, щоб дослідити активність мозку в момент відправки трупа в піч. Зазвичай прилад показував повний спокій, оскільки людина померла кілька днів тому і мозок його давно зупинив свою роботу. Але в міру наближення труни до жерла печі перо електроенцефалографа раптом затремтіло, а потім і зовсім стало виписувати високі зубці, ніби мозок померлого ожив перед небезпекою $\mathrm{i}$ почав зі страху кричати. Як це не здасться фантастичним, але коли вчені розшифрували показання приладу, то визначили, що мозок трупа перед жерлом вогненної печі давав той же сигнал, який дає мозок живої, дуже наляканої людини. Згодом учені пообіцяли телеглядачам прокоментувати все це з наукової точки зору в наступній передачі, однак продовження унікального експерименту (принаймі, показ його по ТБ) не було. Інформацію нині вирішили перевірити в Новосибірську. Мовляв, не дуже зрозуміло, що за люди проводили експеримент у 1996 році, наскільки справне було використовуване обладнання тощо. Місцем проведення досліду став місцевий крематорій. Участь в експерименті взяв лікар-нейрофізіолог. Використовували найсучасніше обладнання. Усі етапи експерименту фіксувалися за допомогою відео- та фотозапису. У результаті при спробі

\footnotetext{
1 За інформацією в Інтернеті Коротков Костянтин Георгійович - доктор технічних наук, заст. директора СПб НДІ фізичної культури, професор Санкт-Петербурзького державного університету інформаційних технологій, механіки й оптики (СПбГУ ITMO), професор університету Холосо (СШААвстралія), президент міжнародного союзу медичної та прикладної біоелектрографіi, президент фірми "Kirlionics Technologies International", член редколегіï журналу "Journal of Alternative and Complementary Medicine" (USA). Коротков К.Г. є автором 6 книг, перекладених на англійську, німецьку та італійську мови, а також понад 200 статей, опублікованих у журналах з фізики та біології; автор 15 патентів.
} 
відправити тіло померлої в піч жодної активності мозку не вдалося зафіксувати [2].

Неможливо зрозуміти, чому настільки разючий факт настільки довго не має однозначного трактування? Чому не досліджують сучасні криміналісти можливість реакції клітин тіла жертви при наближенні до нього вбивці? ${ }^{1}$ Існують також дослідження, результати якого побічно підтверджують потенційну ефективність описаного прийому розслідування вбивств у минулому. Нині отримала визнання фітопсихологія (від др грец. Phyton - «рослина»). Це дисципліна, що вивчає поведінкові реакції рослин і форми прояву цих реакцій. Людина починає освоювати мову природних об'єктів і використовувати його у своїх цілях. 3 давніх-давен, наприклад, існує звичай погрожувати розправою дереву, яке не приносить плоди, закопуючи під його стовбур сокируㄹ. Проте обмежений розмір статті не дозволяє розвивати цю тему. Констатуємо лише головне: все живе на планеті, ймовірно, здатне сприймати i відповідним чином реагувати на шкоду, яка йому завдається людиною³. Не виключено, що існують захисні реакції об'єктів природи, у тому числі заподіяння відповідної шкоди в певних формах. Відомо, наприклад, що жирафи поїдають листя тільки тих акацій, які самотньо стоять. Якщо дерева ростуть купчасто, при поїданні жирафом листя однієї акації вона подає сигнал тривоги й інші дерева починають виділяти в повітря велику кількість отруйної речовини, яка відлякує тварину. Чи не з цієї причини спостерігається високий рівень захворюваності в лісозаготовлювачів? Ми й до сьогодні не зрозуміли природу епідемій людей і епізоотій деяких домашніх тварин, що виникають періодично. Однак якщо замислитися, знайдуться й інші залежності.

Американський учений, поліграфолог, який працював у ЦРУ США, фахівець $з$ детекторів брехні Клайв Бекстер Грувер Клівленд (англ. Grover Cleveland «Cleve» Backster, Jr., 27 лютого 1924 - 24 червень 2013) вважається сучасним першовідкривачем первинної перцепції (сприйняття) в рослин. У лютому 1966 року він під'єднав свою кімнатну рослину (драцену) через гальванометр до самописця, у результаті чого отримав реєстрацію деяких ритмічних сигналів. Бекстер вирішив перевірити, чи зміняться сигнали, якщо він спалить один лист рослини. Як тільки подумав про це, самописець показав максимальне відхилення, причому експериментатор не встиг навіть доторкнутися до рослини.

\footnotetext{
1 Не отримали розвитку результати ще одного експерименту, про який нижче.

${ }^{2}$ Автор (Б.Г.) зізнається, що застосував одноразово даний спосіб. Закопувати сокиру не довелося, достатньо було показати ії яблуні з відповідним навіюванням. Допомогло!

${ }^{3}$ У Польщі корова, зрозумівши наміри господаря, втекла по дорозі на бойню й попливла на острів. Про це повідомляла Daily Mail. Інцидент стався поблизу польського озера Ниса. Коли співробітники бойні приїхали на ферму за коровою, тварина зламала фермеру руку, протаранила металеву огорожу i, стрибнувши в озеро, попливла на острів. Корова живе на острові вже близько трьох тижнів, не дозволяючи наближатися до неї більш ніж на 70 метрів. Коли до втікачки намагалася наблизитися команда рятувальників, тварина знову стрибнула у воду й перепливла на сусідній острів, подолавши 50 метрів. Ситуацією зацікавився польський політик Павло Кукіз. За його словами, своєю волею до життя корова заслужила право на смерть від природних причин.
} 
Бекстер продовжив досліди. За його дорученням у кімнаті, де знаходилася рослина філодендрон, асистент убивав курчат і жаб, кидав в окріп живих рибок. Після чого Бекстер проводив «очну ставку», підводячичи до рослини-свідка різних людей. Рослина безпомилково ідентифікувала «шкуродера», видаючи імпульс, відповідний панічному страху! Про підсумки першого і найзначнішого відкриття Бекстер писав у своїй науковій статті «Свідоцтво наявності у рослин первинної перцепції», яка була опублікована в американській пресі в 1968 році і в інших книгах. Цей експеримент 3 рослинами і креветками викликав цілу бурю в науковому світі Америки та Європи. Масла у вогонь підлила книга Пітера Томпкінса і Кристофера Берда «Таємне життя рослин», яка вийшла в США в 1973 році. У ній детально описувалися не тільки досліди Бекстера, а й інші дивовижні експерименти в галузі біокомунікації.

За минулі роки в США та Європі відбулося багато дискусій, конференцій, а також видано безліч публікацій на тему біокомунікації, як у загальному значенні, так і 3 приводу дослідів Бекстера зокрема. Науковець Клайв Бекстер усі ці довгі роки наполегливо боровся 3 невіглаством у сучасній науці, із небажанням прийняття факту відкриття біокомунікації. Про Бекстера писали як погане, так і хороше. Учений світ у більшості зустрічав досліди Бекстера зі значним скепсисом й упередженням, а прості люди висловлювали своє захоплення відкриттю науковця, популярність якого зростала по всій Америці. Сам Клайв Бекстер неодноразово виступав по телебаченню, радіо і в пресі, а також одного разу навіть виголосив промову перед однією з комісій конгресу США. Повсюди Бекстер із надзвичайною впертістю відстоював свою точку зору про наявність первинної перцепції й необхідності серйозних досліджень у цій галузі.

У результаті цих багаторічних праць поняття біокомунікації таки прижилося в науковому світі. І сьогодні вже нікого не здивуєш розповіддю про те, що в нашому світі існує ще не пізнана форма обміну інформацією та енергією, яка вивчається в галузі біокомунікації. І сьогодні безліч учених, а також серйозні наукові інститути Заходу та Сходу переймаються цією проблемою.

Судячи з публікацій, здатність рослин впізнавати вбивцю була реалізована в США і в слідчій практиці. В одному з приміщень великої бібліотеки штату Іллінойс виявили черговий труп задушеної дівчини. Злочин належав до складу серійних. Невстановлений убивця отримав прізвисько Книжковий Хробак, оскільки скоював злочини в бібліотеках. Підозрювати ж можна було кожного чоловіка, який цього дня відвідав бібліотеку. Однак запросили експерта 3 детекторів брехні. Він оглянув місце злочину, для чогось зняв зі стіни кашпо з рослиною і встановив його в одному з кабінетів бібліотеки. Там же пояснив, що рослина - це єдиний свідок злочину, і в такий спосіб можна «впізнати» злочинця! Експерт під'єднав до прикореневої частини рослини спеціальні датчики, подібні до електродів детектора брехні. Секретар бібліотеки телефоном запопросив 
усіх читачів - а їх виявилося кілька сотень! - прийти для перереєстрації абонемента. Щоб не відлякнути злочинця, викликали як чоловіків, так i жінок. Усіх по черзі запрошували в кабінет, де стояла рослина, і просили розписатися в документах. Експерт постійно знімав показання з рослини стежив за напругою електричного поля. На одного чоловіка, викладача коледжу середніх років, рослина раптом зреагувала: на екрані монітора синусоїди металися від мінімальних величин до максимальних. Експерт велів встановити стеження саме за цією людиною. Минув місяць. Викладач кожен день відвідував коледж, а ввечері повертався додому. Лише одного разу після роботи він відправився до бібліотеки сусіднього міста. У читальній залі підсів до молоденької студентки, заговорив ... Чоловіка заарештували, коли він зупинив між поверхами бібліотечний ліфт i накинув на шию дівчини зашморг. Таким чином справа Книжкового Хробака була успішно завершена. Так уперше за останні тридцять років поліцейські США відкрито заявили в пресі про використання рослин у якості свідків злочинів.

В Україні, на жаль, такої практики не існує. Неможливо й знайти приклади повторення подібних випадків розкриття злочину в США або ж інших країнах. Ідея занепала в імлі критичного неприйняття. Проте немає потреби доводити важливість методики для криміналістів. Чому ж тоді щоразу, маючи все більш досконалу техніку, ми не намагаємося повторити досліди Бекстера, поширивши їх не тільки на кімнатні рослини, але і в живій природі ? Питання ... питання ... питання ...

Зникли в темряві науки і слідчої практики найближчі за часом результати перспективних досліджень. Так для з'ясування причин смерті Костянтин Георгійович Коротков також досліджував трупи. «Мої експерименти, - писав він, - стали можливі завдяки методу, створеному в Росії більше століття тому. Ім'я науковця, на жаль, було забуте, а в 20-х роках XX століття знову відроджене винахідниками 3 Краснодара, подружжям Кірліан. Суть цього методу така: в електромагнітному полі високої напруги навколо живого об'єкта, чи то зеленого листа ,чи то пальця, виникає променисте світіння. Причому характеристики цього світіння безпосередньо залежать від стану енергетики об'єкта. Навколо пальця людини здорової, життерадісної, світіння яскраве й рівне. Будь-які розлади організму, що принципово важливо, не тільки вже виявлені, але нові, ще не виявлені в органах і системах, розривають ореол, що світиться, деформують його і роблять більш тьмяним. Зараз уже сформований i визнаний у медицині спеціальний діагностичний напрям, який дозволяє по неоднорідностях, кавернах і затемненнях на кірліан-знімку робити актуальні висновки про наближення хвороби. Так німецький професор П. Мандель, обробивши величезний статистичний матеріал, навіть створив атлас, у якому різним особливостям світіння відповідають певні відхилення стану організму. Отже, двадцять років роботи з ефектом подружжя Кірліан підштовхнули мене до ідеї подивитися, як змінюється світіння навколо живої матерії в міру того, як вона стає неживою ... Я став досліджувати за допомогою кірліан-фотографій тіла щойно померлих 
людей. Протягом години - трьох після смерті нерухомо зафіксована кисть покійного щогодини фотографувалася в газорозрядному спалаху. Потім знімки, які цікавлять, оброблялися за допомогою комп'ютера, для того щоб визначити зміну параметрів у часі. Зйомка кожного об'єкта тривала від трьох до п'яти днів. Вік померлих чоловіків і жінок коливався від 19 до 70 років, і характер смерті в них був також різним. Однак і це, як не здасться комусь дивним, відбилося на знімках. Безліч отриманих газорозрядних кривих природним чином розбилося на три групи: а) відносно невелика амплітуда коливань кривих; б) невелика амплітуда, проте 3 добре вираженим піком; в) велика амплітуда дуже тривалих коливань. Ці відмінності суто фізичні, і я б не став вам про них згадувати, якби ці зміни так чітко не збігалися 3 характером смерті фотографованих. А такого взаємозв'язку в танатології - дослідження процесу вмирання живих організмів - ніколи раніше не було.

Ось чим відрізнялася смерть людей з трьох названих вище груп:

a) «спокійна», природна смерть старого організму, який виробив свій життевий ресурс;

б) «різка» смерть - теж природна, але все-таки випадкова: у результаті нещасного випадку, тромбу, черепно-мозкової травми чи невчасно наданої допомоги;

в) «несподівана» смерть, раптова, трагічна, якої можна було б уникнути за інших обставин; до цієї ж групи належать самогубства.

Ось він, абсолютно новий для науки матеріал, - характер відходу 3 життя в буквальному сенсі слова висвічується на приладах ...

Тривалість переходу в різних групах теж різна:

а) «спокійна» смерть виявила в моїх експериментах коливання параметрів світіння протягом 16 - 55 годин;

б) «різка» смерть призводить до видимого стрибка або за 8 годин, або наприкінці першої доби, а за дві доби після смерті коливання сходять до фонового рівня;

в) при «несподіваній» смерті коливання найбільш сильні й тривалі, їx амплітуда зменшується від початку до кінця експерименту, світіння тьмяніє наприкінці першої доби, ѝ особливо різко, - наприкінці другої; крім того, щовечора після дев'ятої і приблизно до другої-третьої години ночі спостерігаються сплески інтенсивності світіння » $[3,4,5,6,7,8]$.

У недавньому листуванні з авторами статті К. Г. Коротков пояснив, що наукове й адміністративне оточення одностайно вважало: «Цього не може бути, тому що не може бути», і тому подальші дослідження науковець припинив. Наукова громадськість і практичні працівники правоохоронних органів поставилися до цього 3 невиправданою байдужістю. Чому?

Звичайно, спірні питання є. К. Г. Коротков проводив дослідження на застарілому обладнанні. Вважається, що характер світіння дуже залежить від атмосферного тиску й вологості (при зниженому тиску й підвищеній вологості воно жовтіє), тому всі експерименти, які не враховують ці 
фактори, не достовірні. Потрібна екранізація приладів від впливу перешкод. $€$, до того ж, і ще ряд факторів. Про необхідність точності експерименту пишуть, але жоден фахівець не провів додаткового дослідження з урахуванням усіх вимог. У всякому разі, немає інформації про його проведення. Створені наукові комітети із лженауки таким чином поспішають виправдати своє існування i гальмують просування досліджень непізнаного $[12$, с. 6]. Вважаємо, не тільки криміналисту, а і будь-якій розсудливій людині зрозуміла важливість і цінність відкриття К. Г. Короткова. Проте - тиша. $€$ сумніви в достовірності - перевірте, доведіть, проінформуйте наукову громадськість. Натомість якщо К. Г. Коротков на правильному шляху - об'єднайте зусилля й поставте відкриття на службу практиці!

Результативність судово-медичного та криміналістичного дослідження трупів багато в чому залежить від можливості достовірного визначення моменту смерті людини. У різних народів, а протягом історії в одних і тих же, поняття життя і смерті варіювалося. Вічність душі, потойбічний світ, реінкарнація та ряд інших явищ отримували різне релігійне й інше трактування. Більше ясності було з тілом людини. Тут ознаки смерті були сформульовані медициною. Тисячоліттями вважалося, смерть можна констатувати при зупинці серця й припиненні дихання. Однак і тут виникли парадокси. Як приклад, хвороба, названа іменем російського доктора Жарова, який займався препаруванням баранів, які загинули від ядерного вибуху. Хвороба проявлялася в тому, що люди, які працювали в потужних полях, що виникають поблизу епіщентру ядерного вибуху, кілька діб не дихали і не рухалися; їх вважали мертвими й ховали, а після експериментального відкриття Жарова тваринам стали давати можливість відлежатися (відіспатися), а за кілька днів « трупи оживали » [9].

Ось ще кілька історій. У 1911-1917 роках лама Ітігелов був главою всіх буддистів Бурятії, проте на прийом до нього йшли люди різних конфесій, у тому числі й Микола II з родиною. Слава про цілительські здібності ДашіДоржо Ітігелова досягла блискучого Санкт-Петербурга. Проте найголовніше, він зумів підпорядкувати собі час! У 1917 році він склав із себе повноваження глави буддистів Росії і протягом десяти років зміцнював свій дух. 15 червня 1927 року він скликав усіх своїх учнів і сказав їм: «Приходьте до мене через 30 років - подивіться на моє тіло. А через 75 років я до вас повернуся». Учні були розгублені. Ще більше здивувалися вони, коли той сів у позу лотоса й попросив ïx прочитати буддийську молитву «Благопобажання уходящому». Тi відмовилися, адже цю молитву читають лише небіжчикам. Тоді Ітігелов сам виголосив іï і в ту ж секунду перестав дихати. Тіло лами помістили в кедрову труну й поховали, а таємно від влади лише через 30 років. Ченці переконалися, що тіло залишилося нетлінним, вони виконали необхідні обряди, переодягли покійного ламу і перепоховали. Другий раз монахи переконалися в безпеці тіла в 1973 році, а витягли Ітігелова з-під землі лише 10 вересня 2002 року, рівно через 75 років після смерті, відповідно до волі вчителя. Саме тут і почалося найцікавіше, зрозуміло, для людей, далеких від буддизму. Судмедексперт, який був присутній на ексгумації, оглянув тіло й попросив скликати комісію: раніше він такого ніколи не бачив! Адже лама був не просто впізнаваний зовні 
- він зберіг усі ознаки живої істоти: залишався теплим і в нього, як і раніше, була м'яка, еластична шкіра. У людини, яка 75 років пробула в труні, на місці були вуха, очі, пальці, зуби, вії з бровами! У нього гнулися суглоби всі без винятку! Ітігелова перенесли в Іволгинський дацан, спеціально побудований для нього, переодягли в нове й помістили під скляний ковпак, який хіба що захищає від пилу. До жодних інших хитрощів для збереження лами буддисти не прибігали. Проте з тих самих пір тіло практично не зазнало змін, хіба шкіра стала трохи грубішою. Лама Ітігелов так само сидів в позі лотоса і навіть час від часу набирав вагу - до 2 кг на рік, а потім знову худ. Лама не експонат, буддисти ставляться до нього як до живого, а тому на «поталу» вчених віддали лише втрачене волосся Ітігелова, а також часточки шкіри і крихітний фрагмент нігтя. Дослідникам з Російського центру судмедекспертизи МОЗ РФ вистачило й цього, щоб визнати неймовірне: «Стан тканин такий, що цілком відповідає прижиттевій характеристиці. Нам не відомі випадки такого збереження, це якась наукова загадка ... За багатьма параметрами тіло Хамболами справляє враження тіла живої людини ... » [10].

Дивовижні результати принесла томографія реліквії, яка зберігається в китайському монастирі. Ченці монастиря Дінхуей у Вуані, який розташований в провінції Хебей на півночі Китаю, побажали просканувати мумію майстра Ци Сян, яка там зберігається. Томографія виявила, що кістки, суглоби й зуби в 1000-річного Ци Сяня як у живого. Незмінним залишився й мозок. Нещодавно мумію позолотили, щоб багатше виглядала. Яким чином тканини мумій буддистських ченців століттями зберігаються в «здоровому» стані, невідомо. Науці невідомо! А буддисти вважають, що вони, ці монахи ,i не мумії зовсім, тому що не вмерли, а впали в сплячку - увійшли в стан самадхи, якого одного разу можуть і вийти [11].

Відомі приклади нетлінності трупів не поодинокі. Проте хіба це виняток чи поширене явище? За сучасними вимогами смерть людини повинна констатуватися за показником відсутності життедіяльності мозку. Однак осцилографи є далеко не в усіх медиків. Та й за часом припинення діяльності мозку, що свідчить про факт смерті людини, єдності в думці не має. Тим часом, мозок є найбільш потужним зберігачем інформації про життя кожної людини. Сучасна наука все впевненіше проникає у таємниці лабіринтів Мнемозіни богині пам'яті, знаходиться на грані зчитування думок живої людини, їі мозку. Для криміналістів - це шлях до розкриття багатьох злочинів. Сховищем інформації не може не бути й мозок померлого. Можливість його дослідження - питання недалекого майбутнього ${ }^{1}$. Певна річ, для майбутніх досліджень i

\footnotetext{
1 Мозок здатний тривалий час жити поза тілом. Ця гіпотеза отримала реальне підтвердження завдяки експерименту, проведеного групою нейробіологів під керівництвом Ненада Сестао (Nenad Sestan) з Сльського університету Вчені протримали мозок свині в живому стані 36 годин після обезголовлювання. Японським вченим вдалося зберігати життєздатність мозкової тканини мишей протягом 25 днів після вилучення 3 черепа гризунів. Про це повідомляє видання Science Alert. За оцінками дослідників, максимальний час активності мозкової тканини міг досягати 100 днів. Метод можна використовувати для збереження призначених для трансплантації органов. Медики вже передчувають приголомшливі нові можливості, які відкриються для експериментів на живому мозку. Адже значно розширюється
} 
слід розробляти методи збереження мозку потерпілих від вбивства? На жаль, у юридичній науці безліч перспективних новацій відкидаються та їх 3 часом забувають. Тому дана стаття - це ніби типовий «глас вопиющего в пустыне». Цей фразеологізм запозичений із Біблії. Він використовується нашими сучасниками і донині, допомагаючи передати марність будь-чиїх спроб знайти бажаний відгук на свій заклик, проте при більш уважному прочитанні уривків 3 Біблії ми розуміємо, що в канонічний текст автор вклав зовсім інший сенс, ніж ми звикли зараз. Пророк в алегоричній формі говорив про те, що прийняття християнської віри не можливе без проведення великої духовної роботи над собою. Замислимося ж, колеги?!

\section{Використані джерела:}

1. Симен Бернард. Река жизни. Москва. Издательство: Мир. 1965. 289 с.

2. Бельшшева Г. (Тайны и загадки № 7).URL: https://vitas1917.livejournal.com/948 413.html (дата звернення 10.08.2019).

3. Коротков К.Г. Экспериментальные исследования активности сознания человека после смерти. «Сознание и физическая реальность» т.1, 1996. С. 2-14.

4. Коротков К.Г. Свет после Жизни. СПб, 1996, 264 с.

5. Коротков К.Г. Основы ГРВ биоэлектрографии. СПб, Изд. СПбГИТМО, 2001.360с. 6. Коротков К. Загадки живого свечения. СПб. 2003. 157 с.

7. Коротков К. Энергия Ваших мыслей. Изд 2-е дополненное. СПб. 2013220 с.

8. Korotkov K.G. The Energy of Health. 2017. 220 p.

9. Лелянова Галина. Болезнь доктора Жарова. URL: http://paranormalnews.ru/news/bolezn_doktora_zharova/2012-02-19-4364 (дата звернення 10.08.2019).

10. Ершова Галина. Хамбо-лама Итигэлов: миф и реальность. URL: http:/ / asiarussia.ru/articles/13957/ (дата звернення 10.08.2019).

11. Здоровый мозг и все внутренние органы 1000-летней мумии буддийского монаха шокировали ученых: исследования принесли поразительные результаты. URL https://dialektika.com.ua/news/44462_1500240408/amp (дата звернення 10.08. 2019).

12. Розовский Б.Г. Костры инквизиции в храме закона. Голос Украины. 2010. - № 225 (4975). S. 6.

\section{References}

1. Simen Bernard. Reka zhizni. Moskva. Izdatel'stvo: Mir. 1965. 289 p. [in Russian]

2. Belysheva G.(Tayny izagadki №7). URL:https://vitas1917.livejournal.com/948413. html (accessed 10/08/2019) [in Russian].

3. Korotkov K.G. Eksperimental'nyye issledovaniya aktivnosti soznaniya cheloveka posle smerti. «Soznaniye i fizicheskaya real'nost'»Vol. 1, 1996, 2-14. [in Russian].

4. Korotkov K.G. Svet posle Zhizni. SPb, 1996, 264 p. [in Russian].

арсенал доступних інструментів і речовин, які можна відчувати. Чи не виникає проблем 3 підключенням електродів до живих тканин, з харчуванням електроніки для інтерфейсів мозоккомп'ютер. Загалом, абсолютно приголомшливі перспективи. Якщо експерименти на людському мозку дозволять (формально для експерименту беруть уже мертвий мозок, а потім його оживляють, що не суперечить законодавству), то медицину найближчим часом чекає багато відкриттів. Джерело: MIT Technology Review 
5. Korotkov K.G. Osnovy GRV bioelektrografii. SPb, Izd. SPbGITMO, 2001. 360 s. [in Russian].

6. Korotkov K. Zagadki zhivogo svecheniya. SPb. 2003. 157 p. [in Russian].

7. Korotkov K. Energiya Vashikh mysley. Izd 2-ye dopolnennoye. SPb. 2013220 s. [in Russian].

8. Korotkov K.G. The Energy of Health. 2017. 220 p. [in English]

9. Lelyanova Galina. Bolezn' doktora Zharova. URL: http://paranormalnews.ru/news/bolezn_doktora_zharova/2012-02-19-4364 (accessed 10/08/2019) [in Russian].

10. Yershova Galina. Khambo-lama Itigelov: mif i real'nost'. URL: http:/ / asiarussia.ru/articles/13957/ (accessed 10/08/2019) [in Russian].

11. Zdorovyy mozg i vse vnutrenniye organy 1000-letney mumii buddiyskogo monakha shokirovali uchenykh: issledovaniya prinesli porazitel'nyye rezul'taty. URL: https://dialektika.com.ua/news/44462_1500240408/amp (accessed 10/08/2019) [in Russian].

12. Rozovskiy B.G. Kostry inkvizitsii v khrame zakona. Golos Ukrainy. 2010. - № 225 (4975). S. 6 [in Russian].

Стаття надійшла до редколегї 24.05.2019

Розовский Б. Г., доктор юридических наук, профессор, заслуженный юрист Украины, заведующий кафедрой правоведения Восточноукраинского национального университета имени В. Даля (г. Северодонецк, Украина) Тагиев C. P., доктор юридических наук, профессор, заслуженный юрист Украини, начальник кафедры уголовного, уголовно-исполнительного права и криминологии Академии государственной пенитенциарной службы, (г. Чернигов, Украина)

Бочковой А. В., кандидат юридических наук, старший исследователь ведущий специалист научно-исследовательской лаборатории по проблемам предупреждения, пресечения и расследования преступлений территориальными органами Национальной полиции Украины Луганского государственного университета внутренних дел имени Э. А. Дидоренко, (г. Северодонецк, Украина)

\section{«ГЛАС ВОПИЮЩЕГО В ПУСТЫНЕ» - ПОЧЕМУ?}

В статье отмечается, что вся история цивилизации - повсеместное преодоления извечного предубеждения: «этого не может быть, потому, что не может быть». Несмотря на известные свидетельства эффективного применения в 
следственной практике нетрадиционных методов доказывания, наблюдается их игнорирование и отсутствие интереса в необходимости экспериментального их подтверждения или опровержения. При этом современный научно-технический уровень позволяет опытным путем подтвердить или опровергнуть указанные в статье способы получения информации. Подтверждение описанных фактов позволит повысить эффективность предупреждения, пресечения и расследования преступлений. Опровержение же навсегда избавит от бесплодных дискуссий.

Ключевые слова: криминалистика, биокомуникация, энергия, доказательство, доказывание, свидетель, преступление, наказание, уголовная ответственность.

Rozovskij B., doctor of law, professorhonored lawyer of Ukraine Head of the department of law East ukrainian national university named after V. Dahl (Sievierodonetsk, Ukraine) Tagiev S., doctor of law, professor honored lawyer of Ukraine, Head of the criminal department, criminal law and criminology Academy of the state penitentiary service (Chernihiv, Ukraine) Bochkovyi O.,

Candidate of Law, Senior Researcher Leading specialist of the research laboratory on problems of prevention, prevention and investigation of crimes by territorial bodies

National Police of Ukraine Lugansk State University of Internal Affairs of E. A. Didorenko, $\mathrm{PhD}$ in law, senior researcher (Sievierodonetsk, Ukraine)

\section{«THE VOICE OF ONE CRYING IN THE DESERT» - WHY?}

The article notes that the whole history of civilization is a universal overcoming of eternal prejudice: «it can not be, because it can not be». Despite the well-known evidence of the effective use of unconventional methods of inquiry in investigative practice, they are ignored and lack interest in the need for experimental confirmation or refutation.

There are numerous facts in the press that confirm the ability of the human body to provide useful information for investigation even after death. The authors of the article personally communicated with Professor Korotkov Constantine, who confirmed the truth of his experiments, which showed the ability of corpses to respond to external stimuli, as well as to release some energy, the intensity of which depends on the nature of the onset of death.

No development in investigative practice has received phyto psychology: a discipline that studies the behavioral responses of plants and the forms of manifestation 
of these reactions. American scientist, specialist in lie detector Grover Cleveland «Cleve» Backster, Jr., is considered a modern pioneer of primary perception (perception) in plants. Experiments conducted by scientists have proven the ability of plants to respond to external stimuli and to reflect their reaction by energy fluctuations that can be fixed by means of special devices. At the same time, during the reappearance of the source of high oscillations, the plants repeated the reaction without any influence, which indirectly indicated the presence of memory.

On the results of his first and most significant discovery, Bexter wrote in his scholarly article, «The Certificate of Primary Perception in Plants» which was published in the American press in 1968. In recent years, many discussions, publications, conferences on biocommunication, in general, and Bexter in particular, have taken place in the United States and Europe. As a result of these many years of work, the concept of biocommunication has taken root in the scientific world. And today you will not be surprised by the story that in our world there is an as yet unknown form of information and energy exchange that is being studied in the field of biocommunication.

The possibility of applying the Kirlian effect used in the medical field is not investigated in any way.

At the same time, the modern scientific and technical level allows to proactively confirm or refute the ways of obtaining information in the article. Confirmation of the facts described above will increase the effectiveness of the prevention, termination and investigation of crimes. Rejection, however, will permanently save us from futile discussions.

Key words: criminalistics, biocommunication, energy, evidence, witness, crime, punishment, criminal responsibility. 